\title{
Lipid Contain of Three Microalgaes on Culture with Different $\mathrm{pH}$ and Salinity
}

\author{
Inas Fadhilah ${ }^{1}$, Tia Annisa ${ }^{1}$, Endang L. Widiastuti ${ }^{1,2^{*}}$, Henni W. Maharani ${ }^{2}$ \\ ${ }^{I}$ Department of Biology, Universitas Lampung, Jl. S. Brojonegoro. No. 1, Bandar Lampung, Indonesia \\ ${ }^{2}$ Coastal and Marine Research Centre, Universitas Lampung, Jl. S. Brojonegoro. No. 1, Bandar Lampung, Indonesia \\ *Corresponding author.Email: elwidi@yahoo.com
}

\begin{abstract}
Three species of microalgae were used in this study, namely Nitzschia sp., Porphyridium sp., and Tetraselmis sp., which collected from the Lampung Agency of Maricultures - Ministry of Coastal and Marine Affairs. They were cultured in room temperature with 12:12 day light and given different salinities and $\mathrm{pH}$ for treatment groups with complete randomized design. Nitzschia sp. and Porphyridium sp. were treated within factorial design $2 \times 2$, namely 20 and $40 \mathrm{ppt}$ in salinities and 5 and $10 \mathrm{in} \mathrm{pH,} \mathrm{while} \mathrm{the} \mathrm{Tetraselmis} \mathrm{sp.} \mathrm{was} \mathrm{given} \mathrm{with} \mathrm{factorial} \mathrm{3 \times 3,} \mathrm{namely} \mathrm{10,} \mathrm{15,} 20$ ppt of salinities and 5, 8, $9.5 \mathrm{in} \mathrm{pH}$. All the cultures for 7 days were replicated 3 times. Analysis of variance followed by LSD at $5 \%$ level of significant was applied to analyse the data on specific growth rate and total lipid contains. The results indicated that highest growth rate of Nitzschia sp. was in $20 \mathrm{ppt}$ of salinity and at $\mathrm{pH}$ of 10 , while Porphyridium sp. was in $40 \mathrm{ppt}$ salinity and at $\mathrm{pH}$ of 5. But the highest lipid content of Nitzschia sp. was in $40 \mathrm{ppt}$ of salinity with $5 \mathrm{pH}$, and Porphyridium sp. was in $40 \mathrm{ppt}$ of salinity and 5 in $\mathrm{pH}$. Tetraselmis sp. had the highest growth rate in $20 \mathrm{ppt}$ of salinity and at $\mathrm{pH}$ of 9.5 , but the highest total lipid of it was in $10 \mathrm{ppt}$ of salinity with $9.5 \mathrm{pH}$.
\end{abstract}

Keywords: Nitzschia sp., Porphyridium sp., Tetraselmis sp., lipid, salinity, $\mathrm{pH}$

\section{INTRODUCTION}

Indonesian waters have an area of 3.1 million square kilometers with a coastline of 80,791 kilometers [1]. Marine resources found in Indonesian waters are very abundant and diverse. Microalgae, including one of the marine resources of Indonesia waters, is possible to be used for the development of industrial use of microalgae [2]. Microalgae have an important role as a primary producer such as in a food chain, because it has the ability to photosynthesize as a high-level plant by absorbing sunlight, water, and carbon dioxide which then is converted into energy

[3]. According to Isnansetyo and Kurniastuty [4], microalgae are often used as natural feed, namely Nitzschia sp. and Tetraselmis sp.

Teraselmis sp. consumed by shrimp larvae, ornamental fish, and sea cucumber larvae, while Nitzschia sp. consumed by fish, bivalves, and crustaceans. Besides, microalgae Porphyridium sp. can also be used as natural food by marine organisms.

The potential of microalgae Nitzschia sp., Porphyridium sp. and Tetraselmis sp., besides as a natural food is can be developed as an alternative source of raw materials of biofuels to replace energy from fossil fuels by creating an alternative source of renewable energy sources. These microalgae have fairly high lipid content [5] that Tetraselmis sp. has 15-23\% lipid content, Nitzschia sp. with amount of $45-47 \%$ [6], and Porphyridium sp. is $14 \%$ [7]. Lipids are organic compounds that found in nature and heterogeneous. Lipids are soluble in non-polar organic solvents (other are pentane, benzene, diethyl ether, alcohol, and chloroform), but difficult to dissolve in water.

The growth of microalgae is generally influenced by environmental conditions such as salinity and $\mathrm{pH}$. Microalgae will accumulate greater lipids when the environmental conditions are abnormal or environmental stress [3]. Widianingsih et al., [8] states that microalgae adaptation will tend not to spend a lot of energy, because they survive by using lipids in their body. Microalgae carry out photosynthesis using carbon dioxide $\left(\mathrm{CO}_{2}\right)$ and its accumulation results are formed as aside of carbohydrates and lipids. Based on these explanations, it is necessary to study on the ability to produce total lipids of microalgae Nitzschia sp., Porphyridium sp, and Tetraselmis sp . on giving osmotic stress in different $\mathrm{pH}$ and salinity. 


\section{MATERIAL AND METHODS}

\subsection{Location and Time of Research}

This research was conducted from November 2018 to February 2019, at the Laboratory of Molecular Biology, Department of Biology, Faculty of Mathematics and Sciences, University of Lampung.

\subsection{Methods}

The study was conducted on a laboratory scale with an experiment method. The method that used in this study was Completely Randomized Design (CRD) with factorial $2 \times 2$

of mikroalga Nitzschia sp. and Porphyridium sp., within salinity of 20 and $40 \mathrm{ppt}$ and water $\mathrm{pH}$ of 5 and 10. Each of microalgae was using 4 treatments with 3 repetitions. The factorial of Tetraselmis sp. are $3 \times 3$ with salinity 10 ,

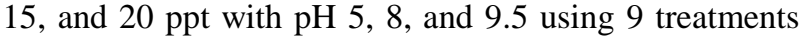
and 3 repetitions.

The culture process of microalgae was done in a 3 liter glass culture bottle. Microalgae that contained in bottles were given 28 watts or 8.400 lux light bulbs as many as five pieces (see Figure 1). Each bottle is bubbling with an aerator to help the growth of microalgae.

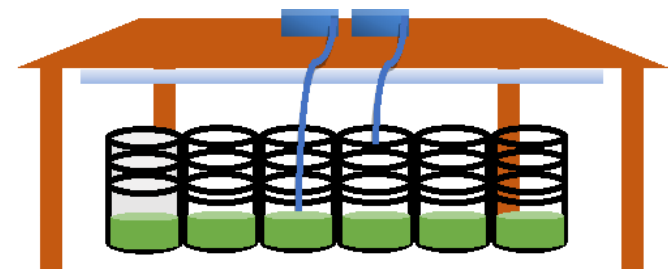

Figure 1 . Illustration of Study Design

\subsubsection{Preparation media and culture sites of microalgae}

Sterilized seawater using UV sterilizer then ozonated for 15 minutes at the Center for Marine Cultivation Development of Lampung Agency of Mariculture. Then the sea water treated with different $\mathrm{pH}$ and salinity as those mentioned in previous design.

\subsubsection{Nutrients of microalgae}

Nutrition or feed given is Conwy pro analyst (PA) fertilizer. Conwy PA fertilizer consists of macro and micro elements. Macro elements consist of $\mathrm{Na}_{2}$ EDTA (45 g), $22 \mathrm{FeCl}_{3} .6 \mathrm{H}_{2} \mathrm{O}(1.50 \mathrm{~g}), \mathrm{H}_{3} \mathrm{BO}_{3}$ (33.6 g), $\mathrm{NaH}_{2} \mathrm{PO}_{4} .2 \mathrm{H}_{2} \mathrm{O}(20 \mathrm{~g}), \mathrm{MnCl}_{2} .4 \mathrm{H}_{2} \mathrm{O}(0.50 \mathrm{~g}), \mathrm{NaNo}_{3} /$ $\mathrm{KNO}_{3}(84.148 \mathrm{~g} / 100 \mathrm{~g}$ ) with $100 \mathrm{ml}$ aquabidest or distilled water which was added with a solution of Trace Metal Solution which is a micro element that consists of $\mathrm{ZnCl}_{2}(2.10 \mathrm{~g}), \mathrm{CuSO}_{4} .5 \mathrm{H}_{2} \mathrm{O}(2.00 \mathrm{~g}), \mathrm{CoCl}_{2} .6 \mathrm{H}_{2} \mathrm{O}(2.00$ $\mathrm{g}),\left(\mathrm{NH}_{4}\right) 6 \mathrm{Mo}^{2} \mathrm{O}_{2} 4.4 \mathrm{H}_{2} \mathrm{O}(0.90 \mathrm{~g})$. Conwy PA fertilizer was carried out at the beginning of the culture as much as $1 \mathrm{~m} \mathrm{~L} / \mathrm{L} \mathrm{[9]}$.

\subsubsection{Culture of Nitzschia sp, Porphyridium sp and Tetraselmis sp.}

The microalgae that obtained from Lampung Agency of Mariculture were taken as much as $125 \mathrm{~mL}$ per sample, then filtered using filter paper. The filter of microalgae was transferred into a culture bottle which had been filled with $500 \mathrm{~mL}$ of sterile sea water through a boiling process and giving treatment in the form of different salinity and $\mathrm{pH}$. The ratio of microalgae density to sea water is 1: 4 [9]. The study was carried out for 7 days until the peak phase was harvested and a total lipid level was tested at the stationary phase.

\subsubsection{Population Density of Nitzschia sp,} Porphyridium sp and Tetraselmis sp.

The cell density of microalgae populations was determined every day using haemo-cytometer on a microscope with a hand counter. As much as $1 \mathrm{~mL}$ of sample was taken every day using a dropper pipette and then transferred into a culture bottle. Adding 2-3 drops of formaldehyde was used to facilitate the observation of microalgae. As for the cell density formula used was based on Mudjiman [10], and as follows:

$$
\mathrm{T}=\mathrm{N} \times 25 \times 10^{4}(\Sigma \text { cell } / \mathrm{mL})
$$

Noted :

$\mathrm{T} \quad$ : Cell Density

$\mathrm{N}$ : Average number of cells (Number of 5

boxes cells / number of boxes (5))

\subsubsection{Growth rate of Nitzschia sp.,}

Porphyridium sp., and Tetraselmis sp.

Microalgae growth rates was determined as follows [11] namely:

$$
\mathrm{K}=\frac{\log (\mathbb{N})}{n+n} \times 3.22
$$

Noted :

$\mathrm{K}$ : Population growth rate

3.22: Constants

N0: Initial microalgae density

$\mathrm{Nt} \quad$ : Density of microalgae at time $\mathrm{t}$

T0 : Initial time

$\mathrm{Tt} \quad$ : Time of observation $\mathrm{t}$

\subsubsection{Analylis of total lipid levels microalgae}

Nitzschia sp., Porphyridium sp., and Tetraselmis sp.

Analysis of total lipid levels was taken from modification method of Bligh and Dyer [12]. Those three microalgae: Nitzschia sp., Porphyridium sp., and Tetraselmis sp. were harvested at the stationary phase or on the $8^{\text {th }}$ day. The microalgae were dropped with $\mathrm{NaOH}$ $1 \mathrm{~g} / \mathrm{L}$ for 24 hours and filtered by using satin fabric to collect them in the form of a paste. The extraction was applied to each treated groups in order to determine the lipid content by using methanol and chloroform with a ratio of 1: 1 or $(3 \mathrm{~mL}: 3 \mathrm{~mL})$ and were homogenized using vortex for about 1 minute to form 2 phases (above clear and cloudy bottom). Calculation of the percentage of total lipid dry weight as follows: 


$$
\% \text { Total Lipids }=\quad \underline{(\mathrm{A}-\mathrm{B})} \times 100
$$

\section{Noted}

A : Weight of cup + weight of lipid after extraction (grams)

B : Weight of the cup before extraction (grams)

C : Wet sample weight (grams)

\subsubsection{Data analysis of microalgae}

Population density was analyzed by one-way ANOVA to determine the differences in each treatment. LSD was carried out after obtaining the results of variance analysis. Growth rates and total lipid levels were analyzed descriptively. Microalgae density data were analyzed using a transformation formula according to Fowler et al., [13].

\section{$=\underline{\mathrm{Tn}-\mathrm{T} 0} \times 100 \%$}

Noted:

T0 : 0-day initial cell cell culture

Tn $: n^{\text {th }}$ day cell density

$X$ : Increase / Decrease population of microalgae

(\%)

\section{RESULTS AND DISCUSSION}

3.1 Microalgae density of cells Nitzschia sp., Porphyridium sp., and Tetraselmis $s p$.

The following data indicated density of Nitzchia sp. cells on differences in salinity and $\mathrm{pH}$ treatment for 7 days.

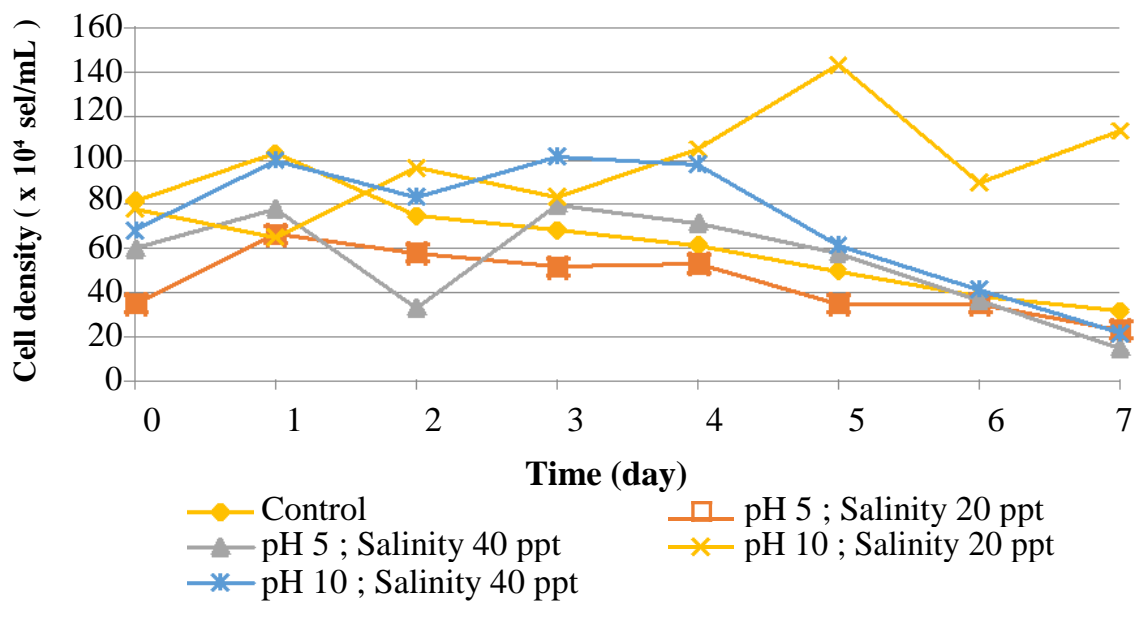

Figure 2. Cell density of Nitzschia sp.

Data on density of Nitzschia sp. cell (Figure 2) was highest in $\mathrm{pH} 10$ and salinity of $20 \mathrm{ppt}$ was $143.33 \times 10^{4}$ cells $/ \mathrm{mL}$ on the fifth day, while the lowest sample was on the seventh day of the $\mathrm{pH} 5$ and salinity 40 was $15 \times 10^{4} \mathrm{sel} / \mathrm{mL}$. On day 5 , the number of cell density increased as much as 143.33 x $10^{4}$ cells $/ \mathrm{mL}$, from $105 \times 10^{4} \mathrm{~s} \mathrm{el} / \mathrm{mL}$ on day 4, while the other samples decreased the cell density. Then on day 6 the cell density decreased to $90 \times 10^{4}$ cells $/ \mathrm{mL}$. The increase in cell density could be influenced by the nutritional content contained in the media and environmental factors [14]. High nutrient content will provide all nutrients needed by microalgae.

On day 1, the treatment group with $\mathrm{pH}$ of 5 and salinity of $20 \mathrm{ppt}$ was different from other treated groups with the average population growth was $84.72 \%$, which was the highest among others. Yet at the day 4, the treatment group of $\mathrm{pH} 5$ and salinity of $40 \mathrm{ppt}$ reached to the top of population growth. Kawaroe et al. [3] indicated that on the 4th to 5th day of cultivation, microalgae were in the exponential final phase and entered the stationary phase. The result of this study (Table 1) also showed similar action that on the $5^{\text {th }}$ day experienced an increase in population growth compared to the previous day, which was $5.93 \%$ on the $4^{\text {th }}$ day and then $82.26 \%$ on the $5^{\text {th }}$ day. 
Table 1 . Growth population percentage of Nitzschia sp.

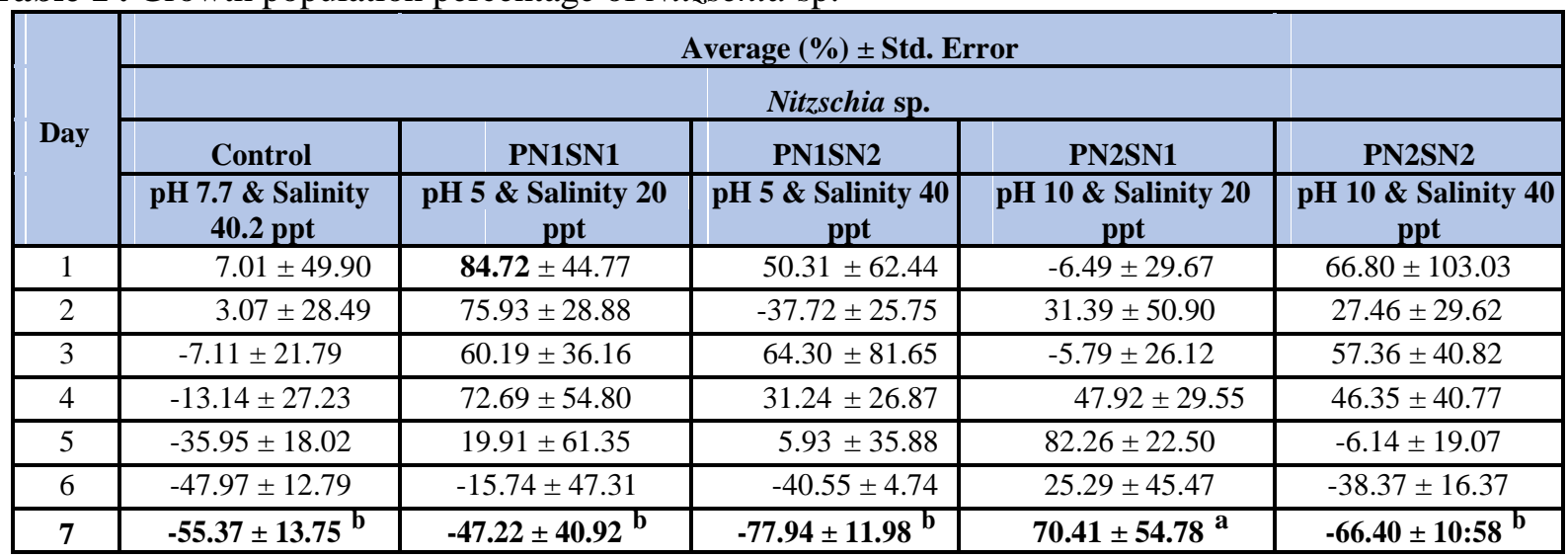

Noted: Different letter notations in the same row indicated significant differences

The following are data on the density of Porphyridium sp. on differences in salinity and $\mathrm{pH}$ cultured for 7 days.

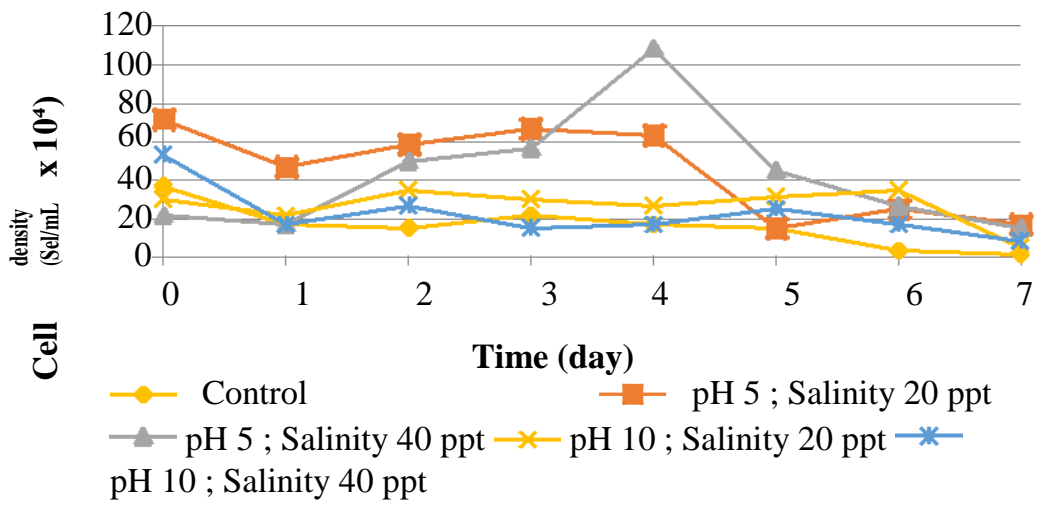

Figure 3. Cell density of Porphyridium sp.

The highest Porphyridium sp. cell density reached by those in $\mathrm{pH}$ of 5 and salinity of $40 \mathrm{ppt}$ (Figure 3 ). It reached up to $108.33 \times 10^{4}$ cells $/ \mathrm{mL}$ on the fifth day, while the lowest group was on the sixth day of the control group of $1.67 \times 10^{4}$ cells mL. Based this figure, the sample cell density began to increase on day 4 to 5 , and then decreased at the $6^{\text {th }}$ and $7^{\text {th }}$ of culture days. Allegedly on the $4^{\text {th }}$ and $5^{\text {th }}$ day, cells were in the exponential phase, namely cell growth had increased because cells were able to adapt well. When experiencing an exponential phase, microalgae cells were actively reproducing by cleavage [15]. On the $6^{\text {th }}$ and $7^{\text {th }}$ day the cell experienced a decrease because on that day, the cells were in the stationary phase, namely the equality between the growth rate and the death rate.

Table 2 . Growth population percentage of microalgae Porphyridium sp.

\begin{tabular}{|c|c|c|c|c|c|}
\hline \multirow{4}{*}{ Day } & \multicolumn{5}{|c|}{ Average (\%) \pm Std. Error } \\
\cline { 2 - 7 } & \multicolumn{5}{|c|}{ Porphyridium sp. } \\
\cline { 2 - 7 } & Control & PP1SP1 & PP1SP2 & PP2SP1 & PP2SP2 \\
\cline { 2 - 7 } & $\begin{array}{c}\mathbf{p H ~ 7 . 8 ~ \& ~} \\
\text { Salinity 39.8 pp t }\end{array}$ & $\begin{array}{c}\text { pH 5 \& Salinity } \\
\mathbf{2 0} \mathbf{~ p p t}\end{array}$ & $\begin{array}{c}\text { pH 5 Salinity 4 0 } \\
\text { ppt }\end{array}$ & $\begin{array}{c}\text { pH 10 \&Salinity } \\
\mathbf{2 0} \mathbf{p p t}\end{array}$ & $\begin{array}{c}\text { pH 10 \& Salinity 40 } \\
\text { ppt }\end{array}$ \\
\hline \multirow{2}{*}{1} & $-48.89 \pm 24.75$ & $-34.92 \pm 8.29$ & $-5.56 \pm 53.00$ & $-33.33 \pm 16.67$ & $-67.96 \pm 6.22$ \\
\hline
\end{tabular}




\begin{tabular}{|c|c|c|c|c|c|}
\hline 2 & $-58.89 \pm 4.84$ & $-18.25 \pm 16.28$ & $138.89 \pm 105.56$ & $19.44 \pm 32.75$ & $-50.28 \pm 8.61$ \\
\hline 3 & $-38.89 \pm 5.56$ bc & $-6.98 \pm 8.25 b c$ & $150.00 \pm 28.87^{a}$ & $13.89 \pm 36.11^{b}$ & $-69.26 \pm 9.65^{c}$ \\
\hline 4 & $-53.33 \pm 10.19 b$ & $-12.06 \pm 10.23{ }^{b}$ & $441.67 \pm 115.57{ }^{a}$ & $-4.17 \pm 18.16^{b}$ & $-67.96 \pm 6.22 b$ \\
\hline 5 & $-56.67 \pm 6.67^{c}$ & $79.05 \pm 0.48^{b c}$ & $113.89 \pm 80.56{ }^{a b}$ & $20.83 \pm 42.29^{a}$ & $-50.00 \pm 9.62^{c}$ \\
\hline 6 & $-88.89 \pm 5.56^{b}$ & $-64.76 \pm 11.23{ }^{b}$ & $19.44 \pm 10.01^{a}$ & $5.56 \pm 29.40^{\mathrm{a}}$ & $-67.50 \pm 3.15^{b}$ \\
\hline 7 & $-94.44 \pm 5.56$ & $-76.98 \pm 8.05$ & $-16.67 \pm 60.09$ & $-83.33 \pm 8.33$ & $-86.94 \pm 7.70$ \\
\hline
\end{tabular}

Noted: Different letter notations state of significant differences

Based on the ANOVA test, there were significant results for the $3^{\text {rd }}$ to $6^{\text {th }}$ day samples. The highest percentage was found on day 4 of the sample $\mathrm{pH} 5$, salinity $40 \mathrm{ppt}$ in the amount $441.67 \%$.
The following data was the density of microalgae Tetraselmis sp. transformation data from the increase or decrease in the growth population of the treatment groups.

Table 3. Tetraselmis sp. Growth population in different salinity and $\mathrm{pH}$

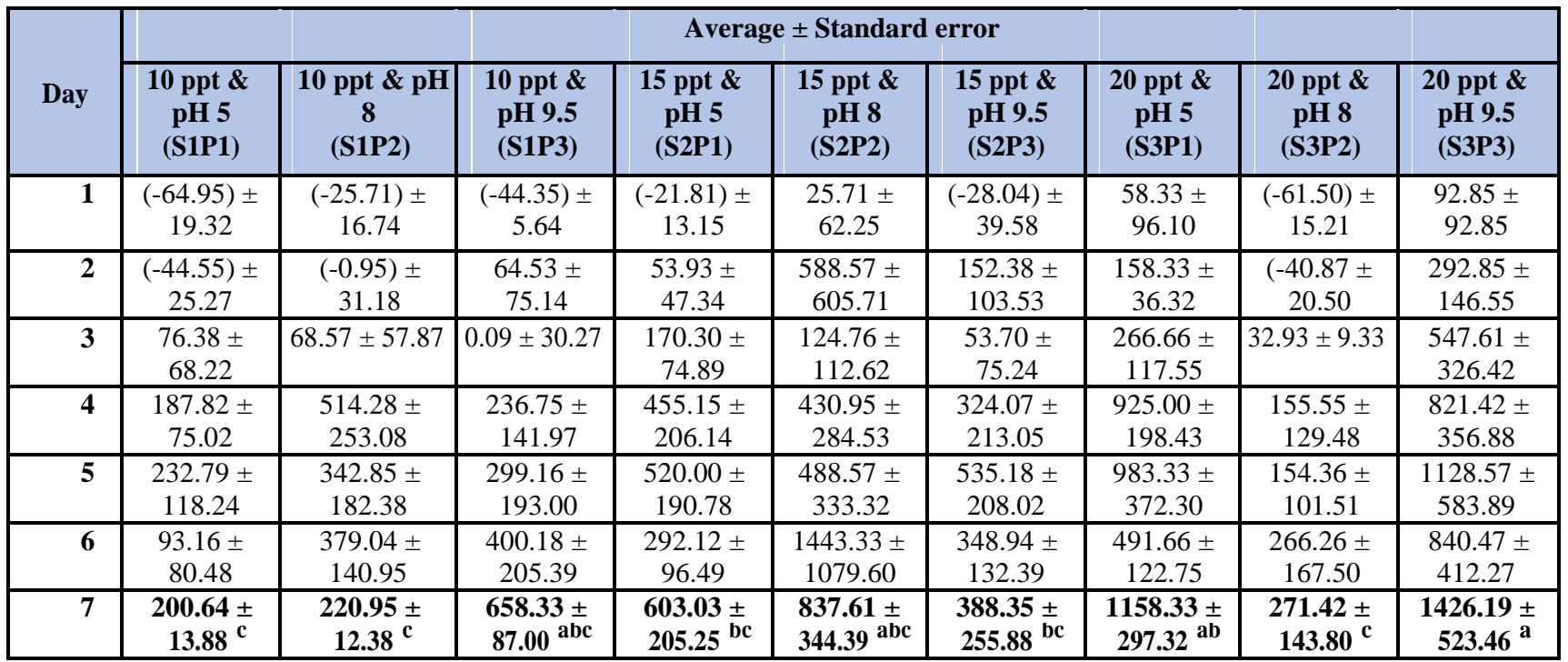

Noted: The different superscript letters indicates difference value between treatments in the BNT test with a significance level 5\% 


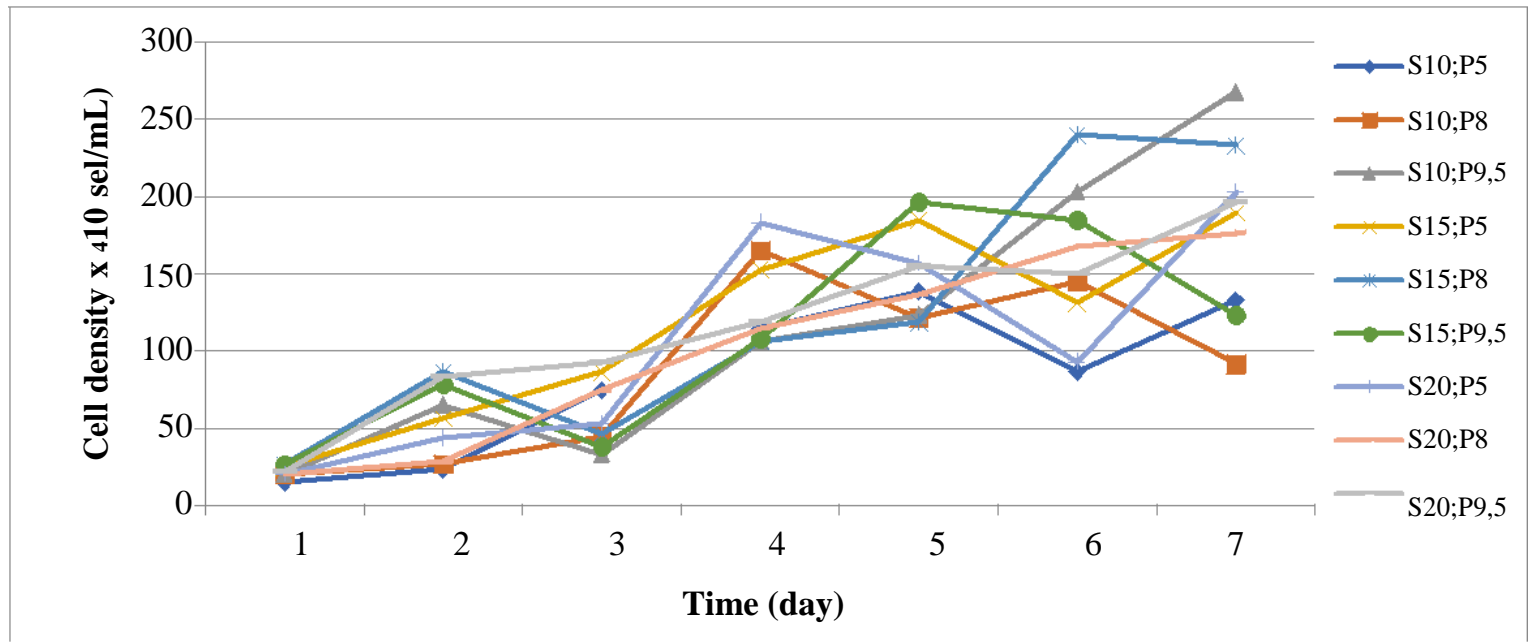

Figure 4 . Cell density of Tetraselmis sp. at different salinity and $\mathrm{pH}$

The percentage of addition or decrease from Tetraselmis sp. microalgae from highest salinity treatment at $20 \mathrm{ppt} \& \mathrm{pH}$ of 9.5 was $1426.19 \%$ with cell density $196.67 \times 10^{4}$ cells $/ \mathrm{mL}$ (Figure 4 ). While the lowest percentage of salinity treatment at $10 \mathrm{ppt} \& \mathrm{pH} 5$ was $200.33 \%$ with cell density $133.33 \times 10^{4}$ cells $/ \mathrm{mL}$ (Figure 4 ). Other study indicated that Tetraselmis sp. cells was more tolerant at the condition from the salinity of $20 \mathrm{ppt}$. Other study indicated that microalgae Tetraselmis sp. had the highest percentage of increasing in population at salinity of $20 \mathrm{ppt}$ with cell density of $677.78 \times 10^{4}$ cells $/ \mathrm{mL}$ [16] . Most of the microalgae tolerated the conditions of environmental changes such as salinity with a very large range and most species of microalgae well performed growth in salinity which was slightly lower than the condition of salinity in its natural habitat [17].

In addition to salinity, acidity $(\mathrm{pH})$ also affects the growth of microalgae. The results obtained by Tetraselmis sp. had the highest cell density at alkaline $\mathrm{pH}$ (pH 9.5), presumably $\mathrm{pH} 9.5$ was suitable for absorption of nutrients by microalgae Tetraselmis sp. and the continuation of optimum enzyme activity so that the metabolic process took place quickly and caused cell density to increase. The $\mathrm{pH}$ level of the media can affect the workings of enzymes in the process of microalgae cell metabolism [18]. The pH level of media also determine the level from solubility and availability of mineral ions that affect microalgae cells in absorbing nutrients

[19]. While the lowest density at $\mathrm{pH} \mathrm{5,} \mathrm{the} \mathrm{cell} \mathrm{did} \mathrm{not}$ get nutrients properly because of the low $\mathrm{pH}$ that interferes with the solubility of mineral ions. The treatment with the initial $\mathrm{pH}$ of medium 5 , the lowest cell density caused by acidic initial $\mathrm{pH}$ can disrupt cell metabolism, and resulting in cells did not optimally absorbing nutrients so that further growth would be disrupted [20].

\subsection{Specific population growth of microalgae Nitzschia sp., Porphyridium sp., and Tetraselmis sp.}

The following graph of the growth rate of Nitzschia sp.

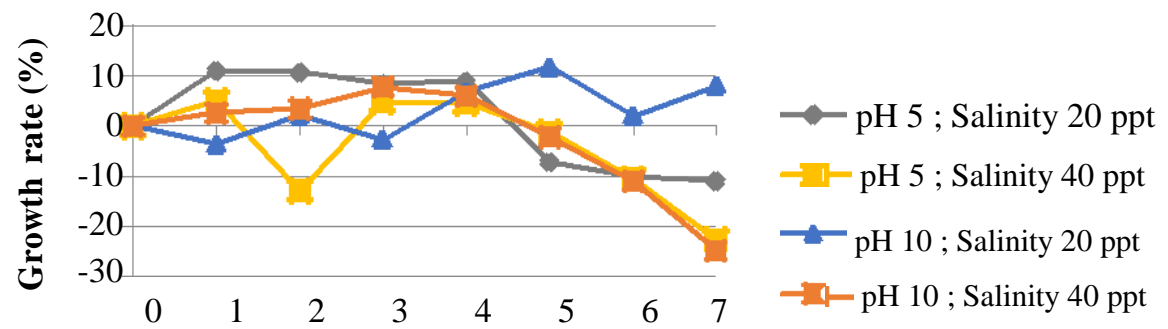

Time (day)

Figure 5. Growth rate of Nitzschia sp.

In figure 5 shows that the growth rate of microalgae Nitzschia sp. fluctuated from day 0 to 7. The sample with the highest growth rate was on the $4^{\text {th }}$ day at $11.04 \%$, which was pH 5 \& salinity of
$20 \mathrm{ppt}$, while the lowest value was found in a sample of $\mathrm{pH} 10$ \& salinity $40 \mathrm{ppt}$ decreased at $24.74 \%$ on the seventh day. 
The higher differences salinity with their original habitat, the more severe for adaptation process in turn the reproduction process and growth was disrupted. The optimum range of salinity in microalgae growth is $25-35 \%$ from dilution using fresh water [21]. Another factor also affects the growth rate of microalgae is acidity. This degree of acidity can affect the level of photosynthesis microalgae [22] and the action of enzymes in the process of metabolism of the cell [18].

The following graph from the growth rate of Porphyridium sp.

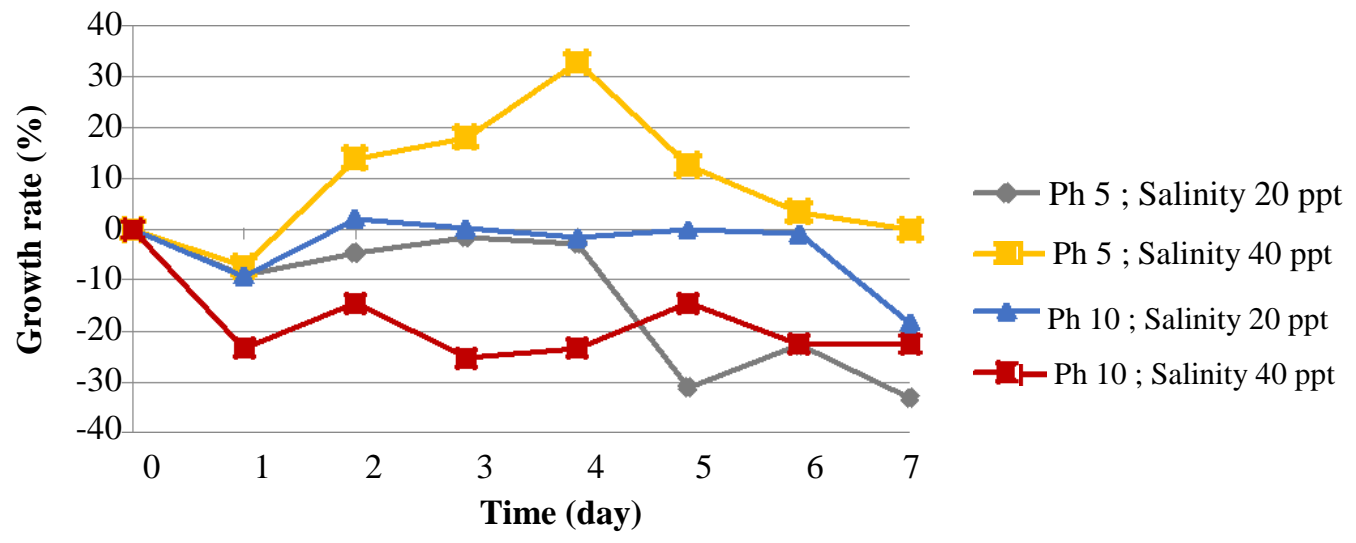

Figure 6. Growth rate of Porphyridium sp.

From this figure (Figure 6), the highest percentage value was $32.89 \%$ in the $\mathrm{pH}$ sample 5 \& salinity $40 \mathrm{ppt}$ in day 4 treatment, while the lowest percentage was on day 7 that decreased at $33.23 \%$ treatment from $\mathrm{pH} 5$ \& salinity $20 \mathrm{ppt}$. The growth rate then increased sharply on days $3,4,5$, and 6 . This was indicated by a change in the graph line that looks different from the other treatment samples. This could be due to the degradation of chlorophyll-a [23] which affects fixation of $\mathrm{CO}_{2}$ becoming decreased and caused the decrease $\mathrm{pH}$ value.

The following graph from the growth rate of Tetraselmis sp. at different $\mathrm{pH}$ and salinity.

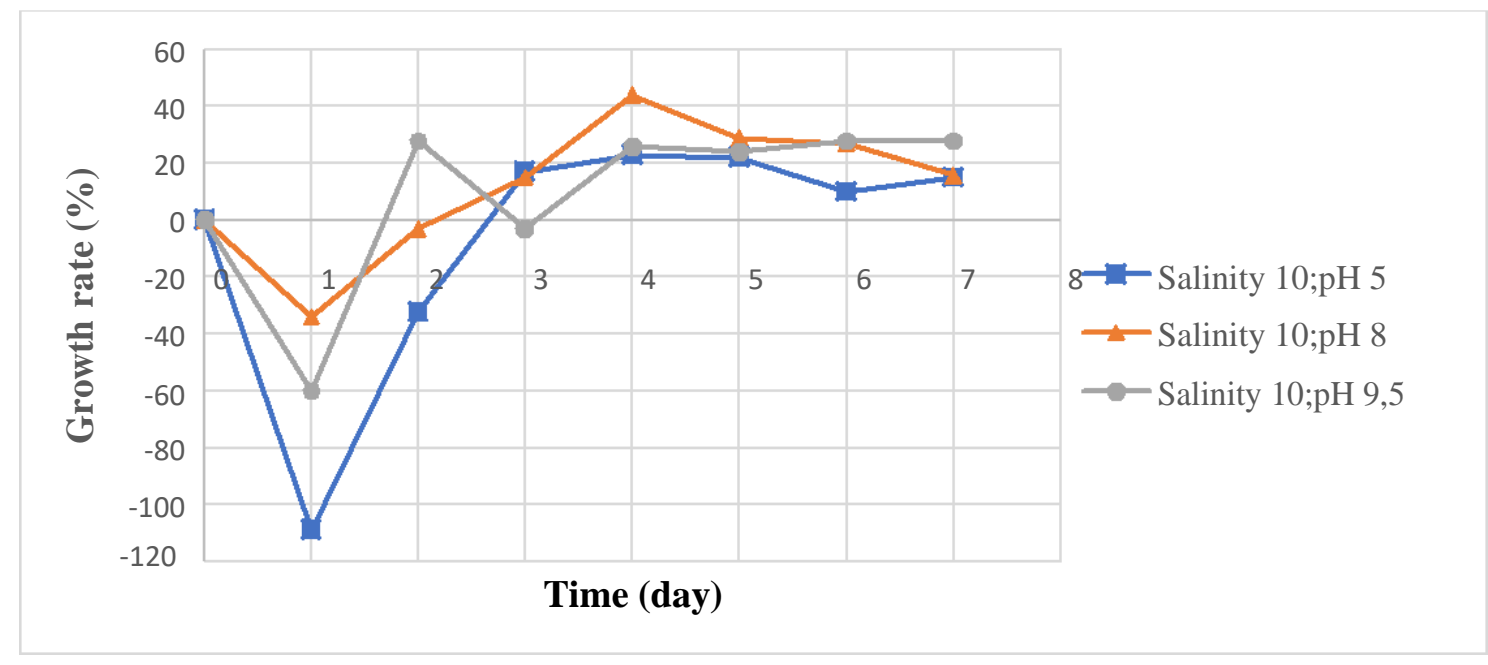

Figure 7. Specific population growth rate of Tetraselmis sp. salinity $10 \mathrm{ppt}(\mathrm{pH} 5 ; 8$; and 9.5)

In Figure 7 indicates that the highest specific growth rate was found on the fourth day at $23 \%$, while at salinity 10 ppt \& pH 8 at $44 \%$, and at salinity 10 ppt \& pH 9.5 was found on the second, sixth and seventh days at $28 \%$. 


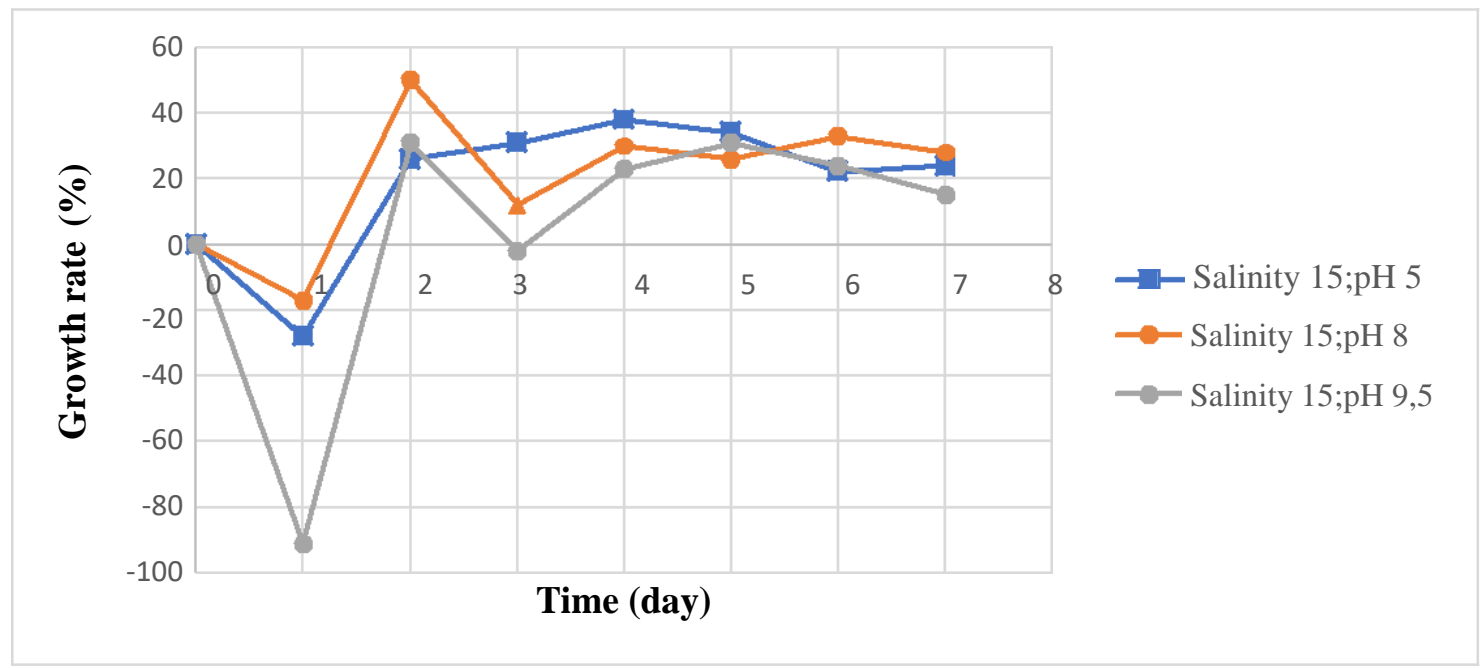

Figure 8. Specific population growth rate of Tetraselmis sp. at 15 ppt salinity (pH 5; 8; and 9.5)

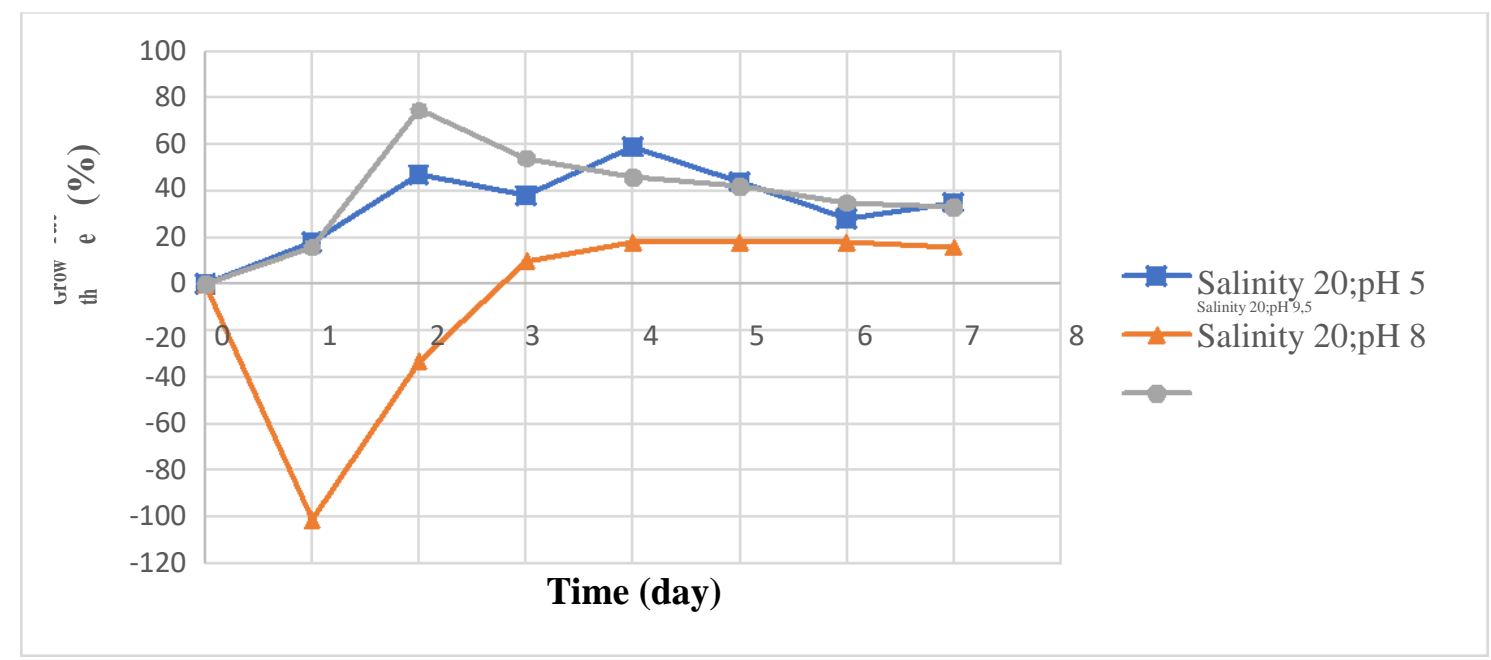

Figure 9. Specific population growth rate of Tetraselmis sp. at salinity $20 \mathrm{ppt}(\mathrm{pH} 5 ; 8$; and 9.5)

In figure 8 , for $10 \mathrm{ppt}$ salinity \& $\mathrm{pH} 5$ the highest specific growth rate was found on day four of $38 \%$, for salinity of $15 \mathrm{ppt} \& \mathrm{pH} 8$ is on the sixth day at $33 \%$, and for salinity $15 \mathrm{ppt} \& \mathrm{pH} 9.5$ was found on the second and fifth days at $31 \%$.

In figure 9 , the highest specific growth rate for salinity is 20 ppt \& pH 5 was on the fourth day $59 \%$, for salinity $20 \mathrm{ppt} \& \mathrm{pH} 8$ was on the fourth, fifth and sixth day at $18 \%$, and for salinity $20 \mathrm{ppt} \& \mathrm{pH} 9.5$ by $75 \%$ on the second day. For each difference in salinity and $\mathrm{pH}$, the highest specific population growth rates were found

Growth of Tetraselmis sp. decreased the growth rate on the seventh day. The microalgae Tetraselmis $\mathrm{sp}$. was in stationary phase or static phase, which was characterized by a population growth rate equal to the death rate so that on the second and fourth days (Figures 6, 7 and 8). This occurrence presumably that cells were still in condition in where treatment media had abundant nutrients, so that microalgae performed in good growth. On the second and fourth day, Tetraselmis sp. cells started to enter the exponential phase which was characterized by increasing population growth rates. Ru'yatin et al. [24] stated that the exponential phase of the Tetraselmis sp. microalgae occurred on the fourth day. When experiencing this phase, microalgae cells are actively reproducing by division.

it is very unlikely that cells can grow. Decreased microalgae cell growth occured due to

lack of nutrient supply, therefore their ability to grow was very low [25]. This was due to the provision of fertilizers 
used as a source of nutrition only at the beginning of the treatment.

\subsection{Total lipid levels of microalgae Nitzschia sp., Porphyridium sp., and Tetraselmis sp.}

The lipid extraction process using the method according to Bligh and Dyer [12] obtained the lipid phase by centrifuging all microalgae samples which can be seen in Figure 10. The results of the three centrifugations were generated, namely the lipid phase, natant, and supernatant. The lipid phase that was used to determine the lipid weight of each sample.

The total lipid levels of microalgae Nitzschia sp. , Porphyridium sp., and Tetraselmis sp. can be seen in Table 4.

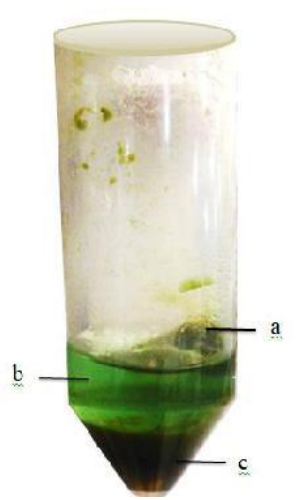

Figure 10. Microalgae pellet after centrifugation (a) natan phase, (b) lipid phase and (c) supernatant phase.

Table 4. Total lipid levels from three types of microalgae

\begin{tabular}{|c|c|c|c|c|c|c|}
\hline $\begin{array}{c}\text { Types of } \\
\text { Microalgae }\end{array}$ & pH & $\begin{array}{l}\text { Salinity } \\
\text { (ppt) }\end{array}$ & $\begin{array}{c}\text { Microalgae } \\
\text { Wet Weight } \\
\text { (g) }\end{array}$ & $\begin{array}{c}\text { Dry Lipid } \\
\text { Mass (g) }\end{array}$ & $\begin{array}{c}\text { Total Lipid } \\
(\%)\end{array}$ & $\begin{array}{c}\text { Absorbance } \\
\text { Value } *\end{array}$ \\
\hline \multirow{5}{*}{ Nitzschia sp. } & Control & Control & 3,000 & 0.045 & 1.50 & 0.044 \\
\hline & 5 & 20 & 3,000 & 0.042 & 1.40 & 0.045 \\
\hline & 5 & 40 & 3,000 & 0.046 & 1.52 & 0.040 \\
\hline & 10 & 20 & 3,000 & 0.041 & 1.35 & 0.083 \\
\hline & 10 & 40 & 3,000 & 0.025 & 0.83 & 0.033 \\
\hline \multirow[t]{5}{*}{ Porphyridium sp. } & Control & Control & 3,000 & 0.022 & 0.73 & 0.042 \\
\hline & 5 & 20 & 3,000 & 0.022 & 0.73 & 0.057 \\
\hline & 5 & 40 & 3,000 & 0.034 & 1.14 & 0.037 \\
\hline & 10 & 20 & 3,000 & 0.020 & 0.66 & 0.016 \\
\hline & 10 & 40 & 3,000 & 0.021 & 0.70 & 0.051 \\
\hline \multirow[t]{9}{*}{ Tetraselmis sp. } & 5 & 10 & 2,0016 & 0.0468 & 2.34 & 0.119 \\
\hline & 8 & 10 & 2,0041 & 0.0973 & 4.86 & 0.059 \\
\hline & 9.5 & 10 & 2.0043 & 0.2864 & 14.29 & 0.124 \\
\hline & 5 & 15 & 2,0048 & 0.0998 & 4.98 & 0.091 \\
\hline & 8 & 15 & 2,0020 & 0.0763 & 3.81 & 0.087 \\
\hline & 9.5 & 15 & 2,0048 & 0.1562 & 7.79 & 0.078 \\
\hline & 5 & 20 & 2.0049 & 0.0478 & 2.38 & 0.057 \\
\hline & 8 & 20 & 2.0050 & 0.1213 & 6.05 & 0.085 \\
\hline & 9.5 & 20 & 2,0054 & 0.1649 & 8.22 & 0.095 \\
\hline \multicolumn{3}{|c|}{ Biosolar } & - & - & - & 0.084 \\
\hline
\end{tabular}

* the absorbance value of a blank solution (aquades) is 0 (zero)

In Table 4, the highest total lipid microalgae Nitzchia sp. was found in the treatment sample at $\mathrm{pH} 4$ and salinity $40 \mathrm{ppt}$ of $1.52 \%$, while the lowest lipid was $0.83 \%$ in the treatment sample at $\mathrm{pH} 10$ and salinity $40 \mathrm{ppt}$. The highest absorbance value after spectrophotometry test was 0.083 at the $\mathrm{pH}$ 10 treatment and 20 ppt salinity.

In Porphyridium sp. microalgae in $\mathrm{pH} 5$ and salinity 20 ppt treatment, obtained a dry lipid mass of 0.022 grams which was the same as the control sample, as well as the percentage of total lipids obtained the same sample with the control of $0.73 \%$, but the absorbance values of the two samples were different. The absorbance value of the sample pH 5 and salinity 20 ppt was 0.057 (highest), while the control sample was 0.042 .

Table 4, it also shows that the highest total lipid levels of Tetraselmis sp. microalgae was found in the salinity treatment of $10 \mathrm{ppt}$ with a $\mathrm{pH}$ of 9.5 was $14.29 \%$. Along with the absorbance value and dry weight obtained which was the highest, compared with the other treatments namely 0.124 and lipid dry 
weight of 0.2864 grams. While the lowest percentage of lipid levels was found in salinity of $10 \mathrm{ppt}$ with $\mathrm{pH} 5$ obtained a value of $2.34 \%$.

In Table 4, Tetraselmis sp. microalgae salinity of $10 \mathrm{ppt}, 15 \mathrm{ppt}$, and $20 \mathrm{ppt}$ could possibly produce high lipid levels. This was due to that microalgae Tetraselmis sp. resistant to high salinity. Study conducted by Ningsih et al. [16], indicated that Tetraselmis sp. when given salinity of $30 \mathrm{ppt}$ (normal) lipid level of $1.26 \%$ was produced, but when salinity had been reduced to 20 ppt the lipid content was greater than normal salinity reached to $2.64 \%$, and when salinity was increased to $40 \mathrm{ppt}$ the lipid content produced was lower up to $0.19 \%$.

From three differences in salinity and $\mathrm{pH}$ (Table 4) the highest lipid content produced at more alkaline $\mathrm{pH}$ was 9.5 (of all salinity). The treatment with the highest lipid levels (10 ppt \& pH 9.5) when compared with the cell density obtained (see Table

3 ) showed an inconsistent comparison. The highest cell density found in the treatment of $20 \mathrm{ppt} \& \mathrm{pH}$ of 9.5 was $1426.19 \times 10^{4}$ cells $/ \mathrm{mL}$, while the highest lipid level was 10 ppt \& pH 9.5 had a cell density of $658.33 \times 10^{4}$ cells $/ \mathrm{mL}$. It was possible for Tetraselmis sp. cells under culture conditions with $10 \mathrm{ppt}$ salinity \& $\mathrm{pH} 9.5$. They were more adaptable by accumulating more lipids. As revealed by Schenk et al[26] microalgae types of Spirulina platensis choose to maintain their survival by producing more lipids when compared to multiplying cells.

Based on the testing of biosolar samples using a UV-Vis Spectrophotometer and with the same wavelength of $680 \mathrm{~nm}$, an absorbance value of 0.084 was obtained (Table 4 ). Shown in Table 4 , the absorbance values resulting from the biodiesel approached the absorbance value on microalgae Tetraselmis sp. in salinity treatment of $20 \mathrm{ppt}$ with pH 8 (0.085) and in microalgae Nitzchia sp. within salinity treatment of $20 \mathrm{ppt}$ with $\mathrm{pH} 10$ (0.083).

\section{CONCLUSION}

The highest population growth from microalgae Nitzschia sp. found in the salinity treatment of $20 \mathrm{ppt}$ with $10 \mathrm{pH}$, while Porphyridium sp. was in the treatment of salinity $40 \mathrm{ppt}$ with $\mathrm{pH} 5$, and Tetraselmis sp. found in a salinity treatment of $20 \mathrm{ppt}$ with a $\mathrm{pH}$ of 9.5 . The highest lipid content of micro-algae Nitzschia sp. and Porphyridium sp. were in salinity treatment of $40 \mathrm{ppt}$ and $\mathrm{pH} 5$, while the microalgae Tetraselmis sp. had the highest lipid level at $10 \mathrm{ppt}$ salinity treatment with $\mathrm{pH} 9.5$.

\section{ACKNOWLEDGMENT}

The authors thank to the University of Lampung for giving funds (2019) of this study, especially to the Coastal and Marine Research Center of the University of Lampung.

\section{REFERENCES}

[1] Wiryawan, B., M. Hkazali, dan M. Knight. Menuju Kawasan Konservasi Laut Berau Kalimantan Timur.Jurnal status sumberdaya pesisir dan proses pengembangan KKL 2005. Kalimantan Timur.

[2] Jawa, I. U., Ridlo, A., dan Djunaedi, A. Kandungan Total Lipid Chlorella vulgaris yang Dikultur dalam Media yang Diinjeksi $\mathrm{CO}_{2}$. Journal of Marine Research. 3. 2014. Pp. 578-585.

[3] Kawaroe, M., Partono, T., Sunnudin, A., Sari, D.W., Agustine, D. Mikroalga :

Potensi dan Pemanfaatannya untuk Produksi Bio Bahan Bakar untuk Biofuel. 2010. Institut Pertanian Bogor. Bogor.

[4] Isnansetyo, A. dan Kurniastuty. Teknik Kultur Phytoplankton dan Zooplankton; Pakan Alami untuk Pembenihan Organisme Laut. Penerbit Kanisius. Yogyakarta. 1995. $106 \mathrm{hlm}$.

[5] Chisti, Y. Biodiesel From Microalgae. Biotechnology Advances. Vol.25. 2007.

[6] Gouveia, L., dan Oliveira, A. N. Microalgae as a Raw Material for Biofuels Production. $J$. Ind. Microbiol. Biotechnol. 36. 2009. pp. 269-274.

[7] Becker, E.W. Microalgae Biotechnology and Microbiology. 1994. Cambridge University Press. New York.

[8] Widianingsih, Hartati, R., Endrawati, H., Yudiati, E., dan Iriani, V. R. Pengaruh Pengurangan Konsentrasi Nutrien Fosfat dan Nitrat Terhadap Kandungan Lipid Total Nannochloropsis oculata. Ilmu Kelautan. 16 (1). 2011. Pp. 24-29.

[9] Balai Besar Pengembangan Budidaya Laut (BBPBL) Lampung. Modul Petunjuk Teknis Kultur Pakan Alami di Balai Besar Pengembangan Budidaya Laut Lampung. 
2001. Direktorat Pengembangan Sumber Daya Kelautandan Perikanan.Lampung.

[10] Mudjiman, A. Makanan Ikan. PT. Penebar Swadaya. 2007. Jakarta.

[11] Hirata, H., I. Andaria, dan S. Yamasaki. Effect of Salinity Temperature on the Growth of The Marine Phytoplankton Chlorella saccharophila. Journal Mem.Fac.Fish. Kaghosima Univ. 30. 1981. Pp. 257-262.

[12] Bligh dan Dyer. Lipid Extraction. Journal of Biochemistry Physiology 37. 1959. P. 911.

[13] Fowler, J., L. Cohen, dan P. Jarvis. Pratical Statistic for Field Biology. Jhon Wiley \& Sons Ltd. England UK Journal. 1998.Pp. 259.

[14] Tri, K. I. Baiq, J. Lalu, A. P. Sri, dan K. Rina. Pengaruh Perbedaan Umur Panen terhadap Kandungan Lemak Nitzschia sp. Journal Biologi Tropis. 15 (2). 2015. Pp. 139-151.

[15] Utomo, N. B. P., Winarti, Erlina, A. Pertumbuhan Spirulina plantensis yang dikultur dengan Pupuk Inorganik (Urea TSP dan ZA) dan Kotoran Ayam. Akuakultur Indonesia. 4 (1). 2005 . Pp. 41-48.

[16] Ningsih, D. R., Widiastuti, E. L., Murwani, S., dan Tugiyono. Kadar Lipid Tiga Jenis Mikroalga pada Salinity yang Berbeda. Jurnal Biologi Eksperimen dan Keanekaragaman Hayati. 4(1). 2017. Pp. 23-29.

[17] Lavens P dan Sorgeloos P (eds). Manual on the production and use of live food for aquaculture.FAO Fisheries Technical Paper. No. 361. 1996.. Rome: Food and Agriculture Organization of the United Nations.

[18] Isnadina, D. R. M., dan Hermana, J. Pengaruh Konsentrasi Bahan Organik, Salinity, dan $\mathrm{pH}$ Terhadap Laju Pertumbuhan Alga. Modul. Institut Teknologi Sepuluh Nopember. 2013. Surabaya.

[19] Nattasya, G. Y. Pengaruh Sedimen Berminyak Terhadap Pertumbuhan Mikroalga Isochrysis sp. Skripsi. Institut Pertanian Bogor. 2009. Bogor.

[20] Prihantini, N. B., Putri, B., dan Yuniati, R. Pertumbuhan Chlorella spp. Dalam Medium Ekstrak Tauge (MET) Dengan Variasi pH Awal. Makara Sains. 9 (1). 2005. Pp. 1-6. Fakultas MIPA. Universitas Indonesia. Depok.

[21] Sylvester, B., D. D. Nelvy dan Sudjiharno. Persyaratan Budidaya Fitoplankton Dalam Budidaya Fitoplankton dan Zooplankton. Biologi Fitoplankton, Budidaya
Fitoplankton dan Zooplankton, Balai Budidaya Laut Lampung Direktorat Jenderal Perikanan Budidaya Departemen Kelautan dan Perikanan. Makara, Teknologi, 9. 2002. Pp. 3-23.

[22] Thajuddin, N., dan Subramaniam, G. Cyanobacterial Biodiversity and Potential Applications in Biotechnology. Current Science Journal 89, 2005. Pp. 47-57.

[23] Sze, P. Algae. Dubuque: 1993. Brown Publisher.

[24] Ru'yatin, Rohyani, I. S., Ali, L. Pertumbuhan Tetraselmis dan Nannochloropsis pada Skala Laboratorium. Pros Sem Nas Masy Biodiv Indon. 1 (2). 2005. Pp. 296-299.

[25] Utami, N. M., Yuniarti, M. S., Kiki, H. Pertumbuhan Chlorella sp. yang Dikultur pada Perioditas Cahaya yang Berbeda. Perikanan dan Kelautan. 3 (3). 2012. Pp. 237-244.

[26] Schenk, P. M., Skye, R., Hall, R. T., Stephens, E., Max, U. C., Mussgnug, J. H., Posten, C., Kruse, O., dan Hankamer, B. Second Generation Biofuel: High Efficiency Microalgae for Biodiesel Production. 2008. Journal Bioenergy. 1: 20-43. 